40 


\section{Calcium Carbonate}

From the Cretaceous Period into the $21^{\text {st }}$ Century

Edited by F. Wolfgang Tegethoff

in collaboration with Johannes Rohleder and Evelyn Kroker 
Cover illustration: Scanning electron microscope image of a coccolith.

A CIP catalogue record for this book is available from the Library of Congress, Washington D.C., USA

Die Deutsche Bibliothek - CIP-Einheitsaufnahme

Calcium carbonate : from the Cretaceous Period into the 21st century / ed. by F. Wolfgang Tegethoff. In collab. with Johannes Rohleder and Evelyn Kroker. - Basel ; Boston ; Berlin : Birkhäuser, 2001 Dt. Ausg. u.d.T.: Calciumcarbonat

ISBN 978-3-0348-9490-6 ISBN 978-3-0348-8245-3 (eBook)

DOI $10.1007 / 978-3-0348-8245-3$

This work is subject to copyright. All rights are reserved, whether the whole or part of the material is concerned, specifically the rights of translation, reprinting, re-use of illustrations, recitation, broadcasting, reproduction on microfilms or in other ways, and storage in data banks. For any kind of use, permission of the copyright owner must be obtained.

The use of registered names, trademarks etc. in this publication, even if not identified as such, does not imply that they are exempt from the relevant protective laws and regulations or free for general use.

The publisher and editor can give no guarantee for the information on dosage and administration contained in this publication. The respective user must check its accuracy by consulting other sources of reference in each individual case.

C 2001 Springer Basel AG

Originally published by Birkhäuser Verlag in 2001

Softcover reprint of the hardcover 1st edition 2001

Printed on Biberist Furiso, calcium carbonate matt art paper $\left(115 \mathrm{~g} / \mathrm{m}^{2}\right)$

Layout: Karina Schwunk, Essen 


\section{Index}

FOREWORD

I. GEOLOGY OF CALCIUM CARBONATE by Jacques Geyssant

1. Features and characteristics of calcium carbonate 2

1.1 Calcium carbonate - a special compound $\quad 2$

1.2 The crystal forms of calcium carbonate - mineralogy 9

2. The limestones - development and classification $\quad 15$

2.1 Sedimentation $\quad 16$

2.2 Diagenesis - from sediment to rock 23

2.3 Classification of the limestones $\quad 24$

2.4 Metamorphism - from limestone to marble $\quad 26$

$\begin{array}{ll}2.5 \text { Carbonatites - extraordinary limestones } & 29\end{array}$

3. Limestone deposits 31

3.1 Recognition of limestones $\quad 31$

3.2 Distribution on the Earth's surface $\quad 33$

3.3 Limestone deposits in the geological ages 36

$\begin{array}{ll}3.4 \mathrm{CaCO}_{3} \text { cycle } & 42\end{array}$

3.5 Industrially exploitable $\mathrm{CaCO}_{3}$ deposits $\quad 44$

II.THE CULTURAL HISTORY OF LIMESTONE

by Johannes Rohleder

$\begin{array}{ll}\text { 1. The history of chalk } & 55\end{array}$

2. Marble and limestone $\quad 69$

$\begin{array}{ll}2.1 \text { Quarrying stones } & 70\end{array}$

$\begin{array}{lr}2.2 \text { Transport, organisation and trade } & 80\end{array}$

$\begin{array}{ll}2.3 \text { The uses } & 97\end{array}$

III. CALCIUM CARBONATE - A MODERN RESOURCE 137

1. The beginnings: Calcium carbonate in glazing putty and rubber 138 by Johannes Rohleder

$\begin{array}{ll}1.1 \text { A chalk industry is born } & 139\end{array}$

$\begin{array}{ll}1.2 \text { Rubber and glazing putty } & 142\end{array}$

$\begin{array}{ll}1.3 \text { From chalk to calcium carbonate } & 156\end{array}$

2. Calcium carbonate - pigment and filler 160 by Eberhard Huwald

2.1 Properties and effects of a filler 164

2.2 Chalk, limestone, marble, PCC - common features and differences 165

$\begin{array}{lr}2.2 .1 \text { Chalk } & 167\end{array}$

$\begin{array}{lc}\text { 2.2.2 Limestone and marble } & 167\end{array}$

$\begin{array}{lr}2.2 .3 \text { PCC } & 168\end{array}$

$\begin{array}{ll}2.2 .4 \text { Areas of application } & 168\end{array}$ 
3.2 Quarrying

3.2.1 Chalk

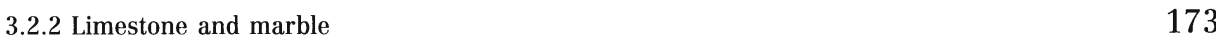

$\begin{array}{lr}3.3 \text { Mineral dressing } & 178\end{array}$

$\begin{array}{lr}3.3 .1 \text { Production of the pre-ground product } & 180\end{array}$

$\begin{array}{lr}3.3 .2 \text { Production of fillers } & 184\end{array}$

$\begin{array}{lr}3.3 .3 \text { Other processes } & 190\end{array}$

$\begin{array}{lr}\text { 3.3.4 Production of PCC } & 190\end{array}$

$\begin{array}{ll}3.3 .5 \text { Storage and packing } & 191\end{array}$

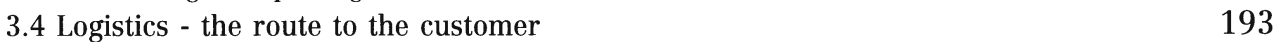

IV. CALCIUM CARBONATE AND ITS INDUSTRIAL APPLICATION 197

$\begin{array}{ll}\text { 1. Paper } & 198\end{array}$

by Christian Naydowski

$\begin{array}{lr}1.1 \text { Calcium carbonate as filler } & 199\end{array}$

$\begin{array}{ll}\text { 1.1.1 Paper manufacturing } & 200\end{array}$

$\begin{array}{ll}\text { 1.1.2 The role of fillers in paper } & 201\end{array}$

$\begin{array}{ll}1.1 .3 \text { Uncoated filled papers } & 204\end{array}$

$\begin{array}{ll}\text { 1.1.4 Neutral paper manufacturing with calcium carbonate } & 207\end{array}$

1.2 Calcium carbonate as coating pigment $\quad 215$

$\begin{array}{ll}\text { 1.2.1 Upgrading of paper and cardboard } & 215\end{array}$

$\begin{array}{ll}\text { 1.2.2 Coated paper qualities } & 218\end{array}$

$\begin{array}{ll}\text { 1.2.3 Pigment properties for paper coatings } & 220\end{array}$

$\begin{array}{ll}1.3 \text { Industrial use of calcium carbonate in the paper industry } & 236\end{array}$

$\begin{array}{ll}\text { 2. Plastics } & 238\end{array}$

by Peter Heß

2.1 The Plastics Market $\quad 240$

$\begin{array}{lr}2.2 \text { Fillers and Reinforcing Agents } & 242\end{array}$

2.3 Calcium Carbonate as Plastics Fillers $\quad 249$

$\begin{array}{lr}\text { 2.3.1 Calcium Carbonate in Thermoplastics } & 250\end{array}$

2.3.2 Calcium Carbonate in Thermosets $\quad 255$

$\begin{array}{ll}\text { 2.3.3 Calcium Carbonate in Elastomers } & 257\end{array}$

$\begin{array}{ll}\text { 2.3.4 Calcium Carbonate in Adhesives and Sealants } & 258\end{array}$

$\begin{array}{lr}2.4 \text { Recent Developments } & 259\end{array}$

$\begin{array}{ll}\text { 3. Surface Coatings } & 260\end{array}$

by Dieter Strauch

3.1 Building blocks for surface coatings $\quad 262$

3.2 Extenders in surface coatings - functions and properties $\quad 264$

$\begin{array}{ll}3.3 \text { The use of calcium carbonates in selected coating systems } & 268\end{array}$

$\begin{array}{lr}3.4 \text { Trends } & 274\end{array}$

4. Calcium Carbonate - A Versatile Mineral 275 by Ralph Kuhlmann

4.1 The use of calcium and magnesium carbonate in agriculture $\quad 275$

$\begin{array}{ll}\text { 4.1.1 The influence of lime treatment on the soil } & 279\end{array}$

4.1.2 The influence of lime treatment on the plant 284

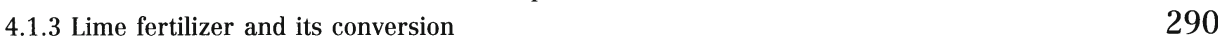


4.2 The use of calcium and magnesium carbonate for forestry 291

4.3 Lime fertilizers and their application in Europe 294

4.4 Calcium carbonate in the feeding of livestock 295

4.5 Calcium carbonate for environmental protection $\quad 296$

$\begin{array}{ll}\text { 4.5.1 Flue-gas cleaning } & 296\end{array}$

$\begin{array}{ll}\text { 4.5.2 Drinking water processing } & 297\end{array}$

$\begin{array}{ll}\text { 4.5.3 Neutralisation of over-acidified water } & 300\end{array}$

4.6 Calcium carbonate - Everyday products 301

by Johannes Rohleder

$\begin{array}{ll}\text { ANNEX } & 313\end{array}$

$\begin{array}{ll}\text { Bibliography } & 314\end{array}$

$\begin{array}{lr}\text { Definitions and Measurement Methods } & 319\end{array}$

Identification of successful processing $\quad 319$

$\begin{array}{ll}\text { Measurement Methods } & 321\end{array}$

$\begin{array}{ll}\text { Glossar } & 325\end{array}$

$\begin{array}{ll}\text { Selection of major standards } & 329\end{array}$

$\begin{array}{ll}\text { Register } & 330\end{array}$

$\begin{array}{lr}\text { Geography } & 330\end{array}$

People and Companies $\quad 330$

$\begin{array}{ll}\text { Technical Terms } & 331\end{array}$

$\begin{array}{ll}\text { Index of important addresses and institutions } & 336\end{array}$

Index of illustrations $\quad 341$ 
Anyone who takes the trouble to look up all the entries that have been filed under "Calcium Carbonate" in a university library will be surprised - if not overwhelmed - by the enormous amount of literature that is concerned in one way or another with this subject. Most of the corresponding books and journals can be assigned to the realms of chemistry, but they also include technical, geological and mineralogical literature. A continued search will eventually unearth works on the history of the arts and architecture. This is because calcium carbonate minerals, be they in the form of chalk, limestone or marble, symbolize defining moments in the history of our culture - the first prehistoric cave drawings in simple coloured chalk, the gigantic limestone blocks used to build the Egyptian pyramids and the marble statues of Michelangelo and Bernini.

This great diversity of what, at first sight, may appear to be only a simple chemical compound makes it rather difficult to explain to a layman what our company is producing and how the product should be defined. This task is much easier if you produce cars or furniture since only experts from different disciplines can associate certain concepts with calcium carbonate. The geologist and mineralogist will envision limestone and chalk or the different forms of marble. The engineer concerned with processing and application technologies will be familiar with the mineral's complicated crystalline properties, while the artist or art historian will think of the flawless "statuario" from the Carrara marble quarries that is sculptured into products that beautify our world.

The different terms and definitions are as numerous as the multitude of "aesthetic" and "useful" items that can be produced from $\mathrm{CaCO}_{3}$ - the chemical formula of calcium carbonate. Moreover, such a diversity and profusion invariably tends to be bewildering rather than clarifying.

This book sets out to overcome this confusing array by indicating the multifarious interdependencies that exist in the world of calcium carbonate - its geology and the his- tory of the arts, its extraction and processing and, obviously, its use in modern industry. Thus, the geologist will find out how a superwhite calcium carbonate slurry is produced from marble for use in paper making. The paper manufacturer, in turn, will be on home ground when the difference is explained between the calcium carbonate coating pigments produced from chalk or marble.

This book is therefore not targeted at a specific professional group with clearly defined knowledge and closely outlined interests, but rather at a very broad spectrum of specialists - among them geologists, processing technicians, paper manufacturers and agricultural scientists - as well as interested laymen who are interested beyond their own particular fields.

The book will reveal how, over a period of many millions of years, coccoliths (Coccolithoporida) have formed mountains composed of a vital filler that has become irreplaceable in modern industry for many everyday products, be they paints, varnishes, plastics or high-quality art paper. This book sets out to fulfil the formidable task of elucidating all these varied aspects - a truly demanding aim that places the highest expectations on the authors and the editorial work for this publication.

Since technical museums are responsible for presenting the sciences, technology and history in a popular form, and since calcium carbonate is extracted by mining methods, it was only natural that the German Mining Museum in Bochum was approached to take over the responsibility of realising this book project. I found two very competent and committed partners in Dr. Evelyn Kroker and Johannes Rohleder who, after three years of intensive and inspiring work, transformed the initial ideas into this remarkable compendium.

At this point I would also like to thank Professor Jacques Geyssant (Paris), Dr. Peter Hess (Cologne), Dr. Eberhard Huwald (Gummern), Dr. Ralph Kuhlmann (Wuppertal), Dr. Christian Naydowski (Oftringen) and Dieter 
Strauch (Oftringen) for their invaluable work. Obviously, I knew beforehand that they were all outstanding experts in their respective fields of "Calcium Carbonate". However, their contributions also proved that, as authors, they had mastered in a very impressive manner the need for scientific exactitude in conjunction with a lucid, generally understandable presentation.

There was also another direct reason for our company to have this book published under the scientific guidance of the German Mining Museum, namely the fact that the company looks upon itself as a modern mining company as it gains calcium carbonate as a raw material from marble, limestone and chalk extracted by quarrying as well as open-cast and partially underground mining of its own extensive deposits in Europe, America and Australia. Moreover, the company refines the raw material by sophisticated technological processes to produce high-quality fillers for industrial production. Some of these processing and refining operations are actually conducted in close co-ordination with the buyers of a products - a partnership that cannot be taken for granted but which is very much to our mutual advantage.

Three years of hard work for a book that is exclusively concerned with calcium carbonate - Is such considerable effort really worth while? The answer is a clear yes! Cal- cium carbonate has not only had a long history that started long before the Cretaceous Period, but it also has a great future that will extend far beyond the 21st century. And it has been the purpose of this book to unite the two - the past and the future. "Calcium Carbonate - From the Cretaceous Period right into the 21st century" - All the current knowledge has been compiled in this book so that it will be available for tomorrow.

If this is not reason enough, then allow me to draw attention to the French philosopher Denis Diderot who, when asked about the reason for his "Encyclopédie ou Dictionnaire raisonné des sciences, des arts et des métiers", gave a very simple reply: "If the only thing to be saved in the Great Flood had been a copy of the 'Encyclopédie', then not everything would have been lost."

And I hope that Denis Diderot would not mind if I, as a person of the 21st century, were to add: In the event that a CD-ROM version of the "Encyclopédie" were to drift in the Great Flood onto some remote piece of land, there would bound to be someone who would revive the knowledge stored in bits and bytes to produce a beautiful art-print binding in the old bibliophile form to satisfy Man's thirst for knowledge.

F. Wolfgang Tegethoff 